\title{
UNDERSTANDING THE SUBJECT'S BEHAVIOR IN THE INTERACTION WITH A DECISION SUPPORT SYSTEM UNDER TIME PRESSURE AND MISSING INFORMATION
}

\author{
Kathiane Benedetti Corso \\ Mauri Leodir Löbler \\ Federal University of Rio Grande do Sul, Brazil
}

\begin{abstract}
The article seeks to determine how time pressure and missing information in decision-making affect the behavior of decision makers. Data was collected through an experimental task of simulating the purchase of a car, which was structured with the AHP (Analytic Hierarchy Process) multi-criteria method in a Decision Support System. When pressured by time, the experimental subjects focused on the car of their choice; whereas with no time pressure, some of them rationalized more, used the information, and did not agree with the chosen car. Assumptions of the Theory of Image justified some findings, indicating that previously structured images in the mind of the decision maker are a way to cope with time pressure. Given the missing information, the use of background knowledge and individual experience were the most prominent coping strategy.
\end{abstract}

Keywords: Behavior of decision makers; Time Pressure, Missing Information, Decision Support Systems, AHP multi-criteria method.

Manuscript first received/Recebido em 09/02/2010 Manuscript accepted/Aprovado em: 22/07/2010

Address for correspondence / Endereço para correspondência

Kathiane Benedetti Corso, Assistant Professor at UNIPAMPA - Campus Santana do Livramento/RS, Doctorate student at PPGA/EA/UFRGS - Post graduation Program in Administration in The School of Administration at the University of Rio Grande do Sul, RS, Brazil - E-mail: kathianecorso@unipampa.edu.br Rua Barão do Triunfo, 1048 - Santana do Livramento/RS - CEP: 97573590. Universidade Federal do Pampa - Telephone: (55) 3243-4540

Mauri Leodir Löbler, Assistant Professor at the Department of Administrative Sciences - Post Graduation Program in Administration - PPGA/UFSM, PhD in Administration from the Administration Post Graduation Program at the School of Administration at the University of Rio Grande do Sul - E-mail: lobler@ccsh.ufsm.br Rua Marechal Floriano Peixoto, 1184 -2. andar - Santa Maria/RS - CEP 97015-372. Universidade Federal de Santa Maria - Telefone: (55) 3220-9296 


\section{INTRODUCTION}

Whether operational or strategic, decisions are part of any human task. When specifically examining the process of decision making in organizations, it is possible to note that it has been changing quickly in recent years, particularly regarding the speed of advancement of information technology and communications. The changeability and dynamics of the environment in which companies act result in a new business environment: from the manager and the chief executive greater preparation for the establishment of strategies and decision making is required (Berto, 2004). Therefore, when studying the decision-making process one should not fail to analyze the influences experienced by the decision maker during this process, since there are several behavioral factors that influence those expected to make the decision.

The study on decision making in companies has been the subject of theoretical and management research, and much has been discovered and analyzed on the subject. Simon (1965) reminds us that in order to understand management, it is important to perceive how people actually solve problems and make decisions. Accordingly, Löbler \& Hoppen (2005) add that research on the decision maker's behavior, human judgment, and choices currently aim at understanding how the human mind works in different situations and with different information, in addition to observing the results.

According to Fisher, Chengalur-Smith \& Ballou (2003) it has been acknowledged that the effectiveness of decision making is influenced by several factors, including the time available before a decision is made. Many decisions in business, especially in economics and finance have to be made under severe time pressure (Kocher \& Sutter, 2006). According to Ahituv, Igbaria \& Sella (1998), several studies have reported the negative effect of time pressure on the effectiveness of decision making, and the pattern of results is fairly consistent. Studies suggest that time pressure results in reduced choice and information processing, as well as in the decrease of the number of alternatives considered.

Availability of information is also influential in the decision process. Many of the day-to-day decisions can involve situations where there is missing information. According to Körner et al. (2007), the missing information topic has received great attention in the research literature on decision. Concerning the missing information in decision making, Jagacinski (1991) ensures that a common problem that people face daily to make decisions is when important pieces of information are missing.

Given the scenario presented up to now, the research question of this present study is: "How do decision-making time pressure and missing information affect the behavior of the decision maker?" Thus, this paper intends to compare two influential factors in decision making - time pressure and missing information - to examine how these can affect the behavior of the decision maker.

The development of the research, based on a theoretical framework, is followed by data collection from individuals characterized as decision makers for the task that guided the study: the simulation of a car purchase, with subjects submitted or not to time pressure and missing information, covered in the method section. After that, the results obtained with the experiment are presented, and these results are further 
discussed and confronted with the literature that supports this theme.

It is noteworthy that, to date, no studies have addressed these concepts applied to decision-making in the Brazilian reality, so this study depicts a challenging idea that is relevant to be studied, and potentially significant for future theoretical and practical contributions.

\section{THE DECISION-MAKING PROCESS AND ITS INFLUENCES}

Organizational tasks are essentially decision-making and problem solving activities (Simon, 1979); they occur all the time, at all levels, and they directly influence organizational performance. Decision making involves a process: a sequence of steps or stages that succeed, called decision-making process. Making a decision is an answer to problems where problems include a set of choices among alternatives (Kingma, 1996 cited in Fisher, Chengalur-Smith \& Ballou, 2003).

Simon (1978) stated that decision makers were limited because they were not aware of the total number of consequences of their decisions, and were also limited by social and personal pressures. Decision making is not always optimal, but it is satisfactory in a certain situation or at a certain moment.

Simon's research aimed at simplifying and understanding complex decision making situations in order to meet the needs of a large number of researchers who had been struggling with the same problem, both in the economic field and in other areas. Simon's great contribution was to bring about the decision-making process in organizations, since the rudimentary theory of the firm, found in traditional economy, was only good to serve as a basis for market behavior studies as a whole, and not for the behavior of the firm individually. Thus, the study of the decision-making process in the firm, conducted by Simon, brought a major breakthrough for Economic Science.

Tversky \& Kahneman (1974), with a similar thought, showed that people are unable to analyze complex situations correctly, when future consequences are uncertain. In these circumstances, according to both authors, individuals seek shortcuts called heuristics. Thus, Tversky \& Kahneman (1974) demonstrated that in situations of uncertainty, human judgment is based on subjective rules, which systematically contradict fundamental propositions of probability.

Continuing in the same line of research, Kahneman and Tversky (1979) showed that individuals reason differently depending on how the problem is presented. The Prospect Theory then emerged, where risk aversion only occurs in the field of gains, but when the possibility of loss is presented to individuals, they tend to be prone to risk. This finding was contrary to the Expected Utility Theory.

According to Markman and Medin (2001), there is now a large number of demonstrations of the limitations in the human decision-making process, and the publication of the Prospect Theory by Kahneman and Tversky (1979) marks a turning point in increasing the interest and influence of psychological models on the decisionmaking process.

Bazerman (2004) also shows that heuristics and biases influence the decision 
making process, he worked on a reinterpretation of the findings of Tversky \& Kahneman and he uses cases applied to illustrate the influence of the above variables. According to the author, the rational model cannot explain how the decision-making process actually happens, since it is based on a set of assumptions that determine how a decision should be made, rather than how a decision is actually made.

Although the decision making process has problem solving as its scope, individual subjectivity in decisions is considerable. Accordingly, several other authors (Simon, 1965; Payne, Bettman \& Johnson, 1993; Svenson, 1996, Pereira \& Fonseca, 1997) address aspects taken by some as factors, and by others as variables or constraints, which influence the decision maker at the moment of decision making, or even throughout the decision making process. Such constrains may be individual factors that limit the quality and quantity of the process, such as limits on reflexes and habits, values, and level of knowledge (Simon, 1965), stress, time pressure, involvement with the task, and mood (Svenson, 1996). The present study addresses time pressure and missing information as factors that influence the decision making process.

\subsection{Influence of Time Pressure in Decision Making}

Time factor is a variable that changes in the new dynamics of companies; thus, it is increasingly necessary to make decisions in a short time; i.e., decision makers should consider this complex picture and its onset quickly, assessing the results of their decisions to the most extent. Pereira \& Fonseca (1997) ensure that when people are rushed, they have a tendency to act impulsively, and the idea that there is not enough time to reach their goals or needs gives rise to general chaos:

Hurrying and speeding produce confusion, and even longer time becomes necessary to solve the problem. The self-imposed illusion that there is no time produces an enormous pressure that leads to panic and its consequences. (Pereira \& Fonseca, 1997, p. 204).

Weber, Smith \& Ram (1987 cited in Smith \& Hayne, 1997) ensure that time pressure is commonly implemented through the use of time limits imposed on completing a task. Thus, time pressure is experienced whenever feasible time for completion of the task is perceived to be shorter than normally required by the activity (Svenson \& Edland, 1987 cited in Fisher, Chengalur-Smith \& Ballou, 2003).

This effect of time pressure may result in the "closing of the mind" (Kruglanski \& Freund, 1983), meaning that people seek cognitive closure and stop considering important aspects of multiple alternatives, engaging superficially rather than processing information in a complete and systematic manner. Table 1 summarizes the studies on time pressure in a decision-making process, showing the main research contributions on this topic, as well as the theme and context in which they were conducted: 


\begin{tabular}{|c|c|c|}
\hline AUTHORS & THEME & MAIN CONTRIBUTIONS \\
\hline $\begin{array}{c}\text { Payne, Bettman \& Luce } \\
\text { (1996) }\end{array}$ & $\begin{array}{l}\text { Decision making in } \\
\text { opportunity-cost (risk) } \\
\text { environments }\end{array}$ & $\begin{array}{l}\text { Individuals speed up their processing of } \\
\text { information, being more selective, and change } \\
\text { strategies from a deeper pattern of processing } \\
\text { (based on alternatives) to a wider one (based on } \\
\text { attributes). }\end{array}$ \\
\hline Smith \& Hayne (1997) & $\begin{array}{l}\text { Business decision in a } \\
\text { Decision Support System } \\
\text { Group }\end{array}$ & $\begin{array}{l}\text { Time pressure changes the difficulty of the task, } \\
\text { influences the decision process, and reduces the } \\
\text { time available to make a decision. }\end{array}$ \\
\hline $\begin{array}{l}\text { Ordóñez \& Benson } \\
\text { (1997) }\end{array}$ & Risk Decision Making & $\begin{array}{l}\text { The subjects change their strategies of decision } \\
\text { in response to time pressure. }\end{array}$ \\
\hline Ahituv, Igbaria \& Sella & $\begin{array}{c}\text { Decision Making in Air } \\
\text { Force }\end{array}$ & $\begin{array}{l}\text { Time pressure generally impairs the } \\
\text { performance of the decision maker. }\end{array}$ \\
\hline De Dreu (2003) & Negotiation Tasks & $\begin{array}{l}\text { The pressure of time produces the "closing of } \\
\text { the mind", resulting in unfounded perceptions } \\
\text { and poor motivation to encode new and relevant } \\
\text { information about the preferences and priorities } \\
\text { of the opponent. }\end{array}$ \\
\hline Kocher \& Sutter (2006) & $\begin{array}{l}\text { Decision Making in } \\
\text { Economy }\end{array}$ & Time pressure leads to the worst decisions. \\
\hline $\begin{array}{l}\text { Rieskamp \& Hoffrage } \\
\text { (2007) }\end{array}$ & $\begin{array}{l}\text { Business probabilistic } \\
\text { inference task with a } \\
\text { higher profit }\end{array}$ & $\begin{array}{l}\text { Under high time pressure, compared to low } \\
\text { time pressure, individuals accelerate the search } \\
\text { for information, using less information, and } \\
\text { staying focused on the most important features. }\end{array}$ \\
\hline
\end{tabular}

Table 1 - Summary of studies on Time Pressure in decision making in different contexts

Source: created by the authors

Table 1 shows that the majority of studies on this subject includes contributions regarding negative effects of time pressure on the decision-making process. Under this variable individuals tend to change their decision strategies (Payne, Bettman \& Luce, 1996; Ordóñez \& Benson, 1997). Still, time pressure impairs the performance of the decision maker (Ahituv, Igbaria \& Sella, 1998), closes the mind resulting in unfounded perceptions (De Dreu, 2003) and leads to worse decisions (Kocher \& Sutter, 2006).

\subsection{Influence of Missing Information in Decision Making}

Information constitutes a basic and indispensable resource for decision making. However, in most cases, information that is available for such judgments is limited or incomplete (Sanbonmatsu et al., 1997). This happens, for example, when a subject is asked to evaluate alternatives of a set of dimensions, but they are not given complete 
information about the values of each alternative across multiple dimensions (Payne, Bettman \& Johnson, 1993).

Birgelen, Ruyter \& Wetzels (2000) state that missing information is unlikely to be ignored or denied by decision makers; and several studies have shown that decision makers tend to reasoning based on the assumption and extrapolation or will predict the missing information of other available information. Table 2 shows the summary of studies on Missing Information in decision making, with the main research contributions on this topic, as well as the theme and context in which they were conducted:

\begin{tabular}{|c|c|l|}
\hline AUTHORS & \multicolumn{1}{|c|}{ THEME } & \multicolumn{1}{|c|}{ MAIN CONTRIBUTIONS } \\
\hline $\begin{array}{c}\text { Ahituv, Igbaria \& } \\
\text { Sella (1998) }\end{array}$ & $\begin{array}{c}\text { Decision Making in Air } \\
\text { Force }\end{array}$ & Full information improves performance. \\
\hline $\begin{array}{c}\text { Ebenbach \& Moore } \\
(\mathbf{2 0 0 0 )}\end{array}$ & $\begin{array}{c}\text { Judgments of } \\
\text { environmental projects }\end{array}$ & $\begin{array}{l}\text { When there is missing information, the } \\
\text { subjects infer missing information from } \\
\text { available information. }\end{array}$ \\
\hline $\begin{array}{c}\text { Kivetz \& Simonson } \\
\text { (2000) }\end{array}$ & $\begin{array}{c}\text { Decision to purchase } \\
\text { laptop, yogurt, and choice } \\
\text { of leisure club }\end{array}$ & $\begin{array}{l}\text { The missing information affects the } \\
\text { preference for the options being considered, } \\
\text { and also tastes and preferences in subsequent } \\
\text { choices. }\end{array}$ \\
\hline $\begin{array}{c}\text { Körner et al. (2007) } \\
\text { Choice of qualified } \\
\text { student to receive } \\
\text { scholarship }\end{array}$ & $\begin{array}{l}\text { When in missing information, decision- } \\
\text { makers give more weight to common } \\
\text { dimensions (alternatives available in all } \\
\text { dimensions), and examine them before unique } \\
\text { dimensions (with missing alternative). }\end{array}$ \\
\hline
\end{tabular}

Table 2 - Summary of studies on Missing Information in decision making in different contexts

Source: created by the authors

In Table 2 it is clear that Ebenbach \& Moore (2000) and Körner et al. (2007) present their contributions with respect to how the subject reacts when faced with a task of missing information, i.e., that individuals infer this information from information already available, giving more weight and common dimensions (with information available) than the unique dimensions (with missing information).

Kivetz \& Simonson (2000) find that contributing to missing information affects the preference of choice, and tastes in later choices of individuals. Ahituv, Igbaria \& Sella (1998) observed that full information improves performance, implying that missing information compromises the individual's performance of task. 


\section{METHOD OF RESEARCH}

This study was supported by experimental research, which according to Fachin (2002), is the research method in which variables are manipulated in a pre-determined manner and their effects are sufficiently controlled and known by the researcher to observe the study, in order to establish causal relationships. Experimental control is achieved by treating people of all the groups from the experiment identically, and the only difference among the groups is the manipulated variable (Cozby, 2006). For purposes of this study, the manipulated variables will be two - time pressure and missing information - the remainder being homogenized in the experimental groups.

The experiment was structured based on a $2 \times 2$ matrix (with missing information versus no missing information $\mathrm{X}$ with time pressure versus no time pressure) to obtain different experimental groups. Missing formation and time pressure variables, given to the decision maker, when combined are structured as follows: (1) task with missing information and with time pressure, (2) task with missing information and with no time pressure, (3) task with no missing information and with time pressure, and (4) task with no missing information and with no time pressure.

The experimental task, which consisted of the choosing of the cars, was a decision task that has as alternatives popular cars, and as attributes or criteria, their characteristics. By comparison, the user was asked to choose and rank the alternatives and attributes according to their preference, and also to state the relevance of their choice. The methodology used for the decision-making task was the AHP-Analytic Hierarchy Process - multi-criteria method, which allows to structure decision in hierarchical levels, determining by the synthesis of values of decision makers a global measure for each of the alternatives, sorting and prioritizing them to the end of the method (Saaty, 1991).

For the task, we created a Decision Support System (DSS) in order to determine how decision makers react to time pressure and missing information. DSS's systems are currently being utilized as a tool for academic research seeking to study the behavior of decision makers. Payne, Bettman \& Johnson (1993) state that one of the key points of the systems that support decisions is the identification of the strategy being employed by each individual, that is, what information the individual seeks, the sequence of information acquisition, the amount of information acquired, and how long the information was examined. At the end of the decision making task the mapping of the choices made during the task was analyzed, and a questionnaire was made after the experiment with the four experimental groups to check the behavior of decision makers.

For the sake of a better understanding of the research method steps, Figure 1 shows a schematic of the route taken, which starts with the construction of DSS AHP MAKH-ER, goes through the validation (math, by user and of mapping) of the Decision Support System AHP MAKH-ER, then the experiment itself, ending with the mapping and post-experiment questionnaire, for the subsequent analysis of the behavior of the decision maker. 


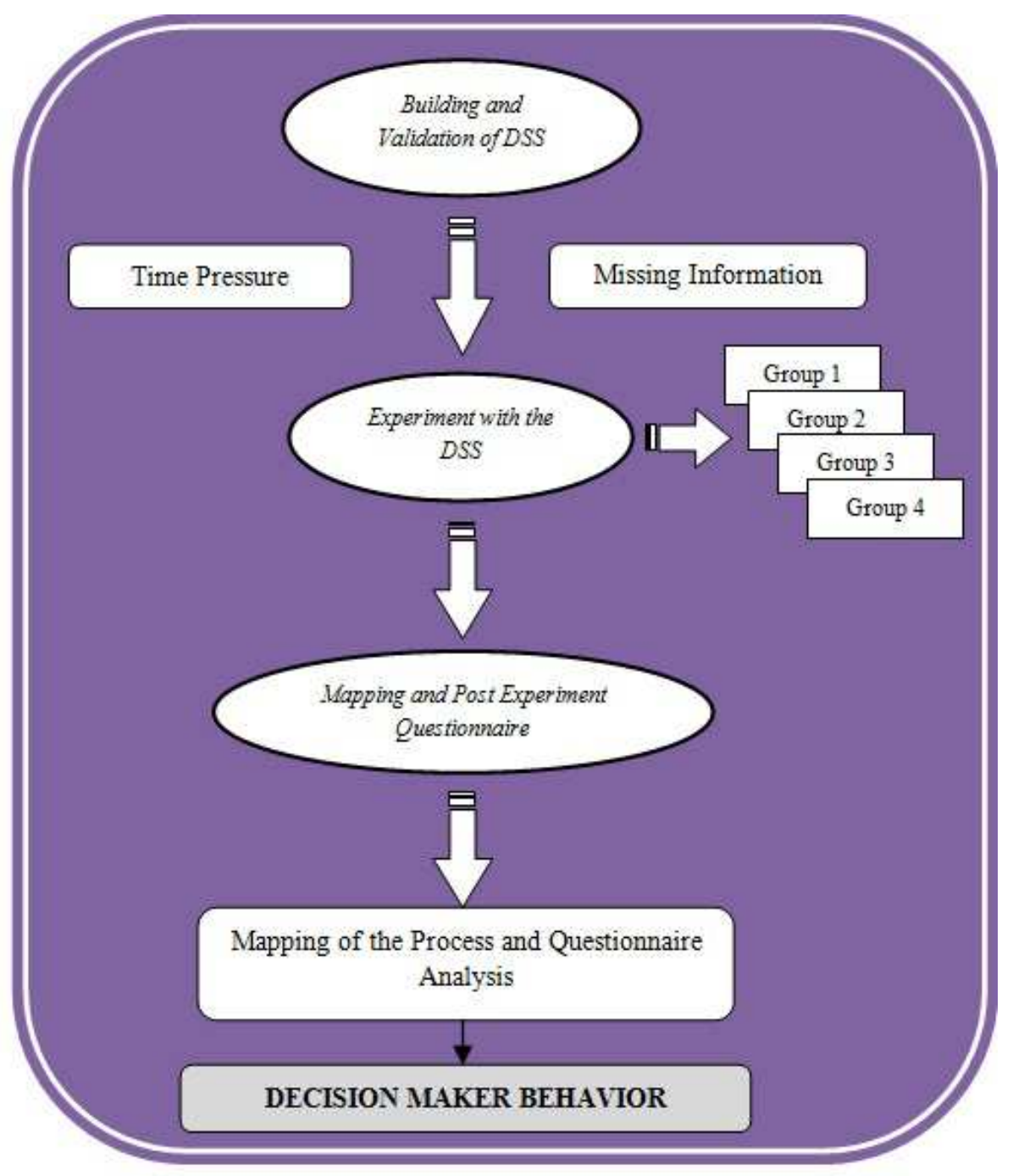

Figure 1 - Schematic of the research method steps

Source: created by the authors

Afterwards, it shows the AHP MAKH-ER system operation and interface. The application of the independent variables - Time Pressure and Missing information - is presented soon after, as well as the research subjects and the experimental design.

\subsection{Operation of the AHP MAKH-ER Decision Support System}

The software AHP MAKH-ER built to research and validated by Corso and Löbler (2010), allows you to create any kind of decision-making task. The underlying mathematical model was based on the AHP - Analytic Hierarchy Process multi-criteria method, known as AHP Method, which according to the judgments and choices of decision makers, ponders the relevance of each alternative and criterion, by using a 
matrix. The system supports individuals in the decision task and helps the researcher in mapping the decision-making process, through computer accesses (logs), i.e., the recording of the movements and accesses made by decision makers.

In the layout of the experimental task (Figure 2), the lines have the three alternatives of choice, that is, the three models of cars available for the choice of decision-makers, and the columns have the attributes of each car, i.e., relevant criteria when buying cars, from Löbler's research (2005). Depending on the clicks, the information remains available.

As the decision maker examines all the values of the alternatives of a given criterion, an automatic pop up screen opens (Figure 2), with a question asking the decision maker to make a pair comparison of each element, in accordance with the AHP methodology. Hence, the decision maker will represent, from a pre-defined scale, their preference among the elements compared. Saaty (1991) recommends that the process of comparing pairs must be implemented using verbal questions.

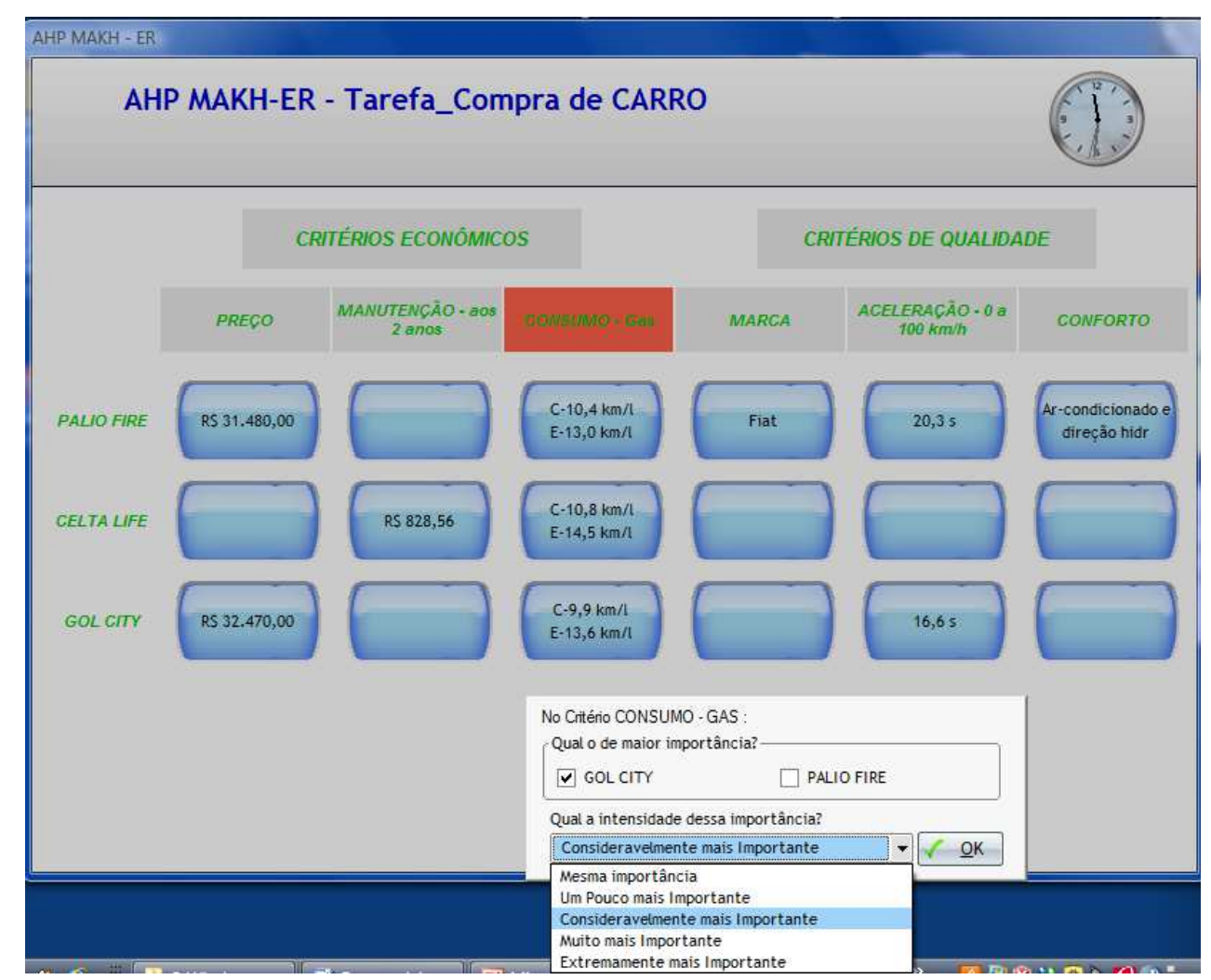

Figure 2- Task screen of AHP MAKH-ER - Task with opening of the judgment screen on the first level

Source: System developed for the research

In the example of Figure 2, the decision maker will have to compare between: Maintenance/Gol City $x$ Maintenance/Palio Fire, Maintenance/Palio Fire $x$ Maintenance/Celta Life, and Maintenance/Gol City x Maintenance/Celta Life, by 
answering the question: "Regarding the Maintenance Criterion, which is the most relevant?", in other words, they will judge which one contributes more to the maximization of the criterion, according to their opinion.

Then it is asked "What is the relevance of this matter?" That is, how many times the Maintenance of Celta Life is more relevant than the Maintenance of Gol City, as in the example. A pairwise comparison of the alternatives is used with its own linear scale, which ranges from 1 to 9, and it is called Fundamental Scale of Saaty, shown in Table 3. The numbers of the scale are not available for the decision maker, because the study of Saaty (1991) has previously determined that the semantic intensity has a corresponding representation in values, and that the individual needs only to manifest semantically.

\begin{tabular}{|c|c|l|}
\hline Scale & Intensity of Relevance & \multicolumn{1}{|c|}{ Description } \\
\hline $\mathbf{1}$ & Same relevance & Both tasks contribute equally to the purpose. \\
\hline $\mathbf{3}$ & A little more relevant & $\begin{array}{l}\text { Experience and judging favor one task in relation to } \\
\text { another. }\end{array}$ \\
\hline $\mathbf{5}$ & Considerably more relevant & $\begin{array}{l}\text { Experience and judging strongly favor one task in relation } \\
\text { to another. }\end{array}$ \\
\hline $\mathbf{7}$ & A lot more relevant & A task is a lot more strongly favored in relation to another. \\
\hline $\mathbf{9}$ & Extremely relevant & $\begin{array}{l}\text { An evidence favors a task in relation to another with the } \\
\text { highest level of reliability. }\end{array}$ \\
\hline
\end{tabular}

Table 3- Fundamental Scale of Saaty

Source: Saaty (1991), adapted by the author

Thus, according to the AHP Method, the answers are converted to numbers within a matrix, given the degree of relevance and priority that they have, ranging from 1 to 9 (Table 3), and which expresses the number of times an alternative dominates or is dominated by the other (Saaty, 1991). The same process, of the pop up automatic screen, will pertain to the other criteria, whenever the decision maker opens all the cells of the alternatives of a criterion. So, after going through the procedure shown in Figure 3 , for all the criteria of a Set of Criteria, a new comparison pop up screen opens to a higher hierarchical level, i.e., to compare each Set of Criteria (criteria of the Economic Group and criteria of the Quality Group), to finally compare the last hierarchical level: the comparison between Economic Criteria and Quality Criteria Groups.

Finally, the weights are acquired and the consistency of the matrix is checked, a process called matrix normalization, (Saaty, 1991). The choice of the final decision should be based on the alternative with the highest score (percentage weight). The final screen of the decision of each user is presented as a vertical bar Table of the choice of the car, based on the alternative with the highest score, with the percentages of each attribute that they judged to be relevant during the task. 


\subsection{Application of Independent Variables: Time Pressure and Missing information}

To characterize time pressure, a few concepts already addressed in the literature were used. Among them, and most importantly, that in which time pressure is experienced through the use of time limits imposed by the completion of a task (Smith \& Hayne, 1997); that in which time pressure is experienced whenever feasible time for task completion is perceived to be shorter than normally required by the task (Fisher, Chengalur-Smith \& Ballou, 2003), and that such time restriction creates a feeling of stress and a need to deal with the restriction of time (Ordóñez \& Benson, 1997).

For the task under study, no literature with reference to the specific time that causes the feeling of stress in individuals has been found. Maule \& Hockey (1993) state that it is difficult for researchers to determine how to vary the time given to provide a comprehensive estimation of the effects of time pressure in decision making. Thus, they show that most studies have operationalized time pressure by adopting a given time, which is any fraction of the usual time to complete the task, without clearly justifying this particular fraction.

Based on such considerations and on the measured time that individuals took to complete the task in the validation of AHP MAKH-ER with users, we chose to set pressure time, by using separatrices, i.e., the quartile list of times checked. To determine, therefore, the time that would put pressure on the individual, the first quartile list was determined, i.e., the periods of time corresponding to the $25 \%$ lowest periods of time found, and the mean of this quartile was later used. Then, by definition, an average of $4 \mathrm{~m}$ and $45 \mathrm{~s}$. was determined. Still, to create the specific scenario and induce a feeling of stress on the individual, it was decided that, in addition to the reduced time to perform the task when submitted to time pressure, three warnings would be given. For the task performed with no time pressure, no time limit was set.

To set a task with missing information, the one considered was that in which some values of certain cells of alternative $\mathrm{X}$ criterion were removed, since the literature states that missing information occurs when not all information is made available to the individual (Körner et al., 2007). Thus, for the version of AHP MAKH-ER with missing information, some values of certain criteria of cars were randomly (by a drawing) removed. In the decision-making task interface that represents the version with missing information, the decision maker finds "No Value" in that cell. Even so, they must proceed with their judgment, having to choose between two alternatives offered.

\subsection{Subjects and Experimental Design}

As the decision-making task is the choosing of a car, the individuals selected as experimental subjects should be knowledgeable of the subject of decision, that is, individuals who often buy cars, subscribe to car magazines, are car enthusiasts, and work in the field, such as mechanics, drivers and car salesmen, people that have one or more of these characteristics. The criterion of background knowledge was therefore used for the selection of the subjects, while Löbler (2005) found this to be an influential variable. After 20 participants were selected for the experiment, they were randomly divided for the application of the decision-making task into four groups of five individuals, according to the inclusion or not of the research independent variables applied in the task (Figure 3). 


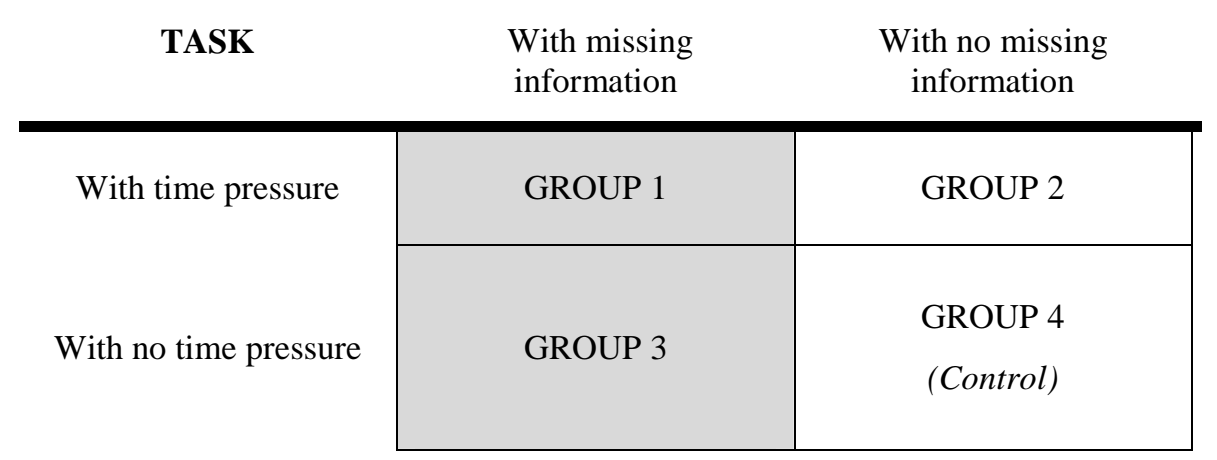

Figure 3 - Standardization of experimental group denomination

Thus, the research design was divided into four groups of experimental subjects, and each group performed the same task of choosing a car and were differentiated by experiencing missing information or not, and time pressure or not in their task.

\section{RESULTS: THE BEHAVIOR OF THE DECISION MAKER}

This section shows the results of the decision-making process mapping, by using computer aid (logs), as for the search for information, and the analysis of questionnaires made to decision makers at the end of the experiment. Such results, when contrasted with the literature, are described separately by an experimental group, in order to examine the differences among the groups submitted to different variables.

\subsection{Process Mapping}

By using logs for the answers of decision makers, it was possible to find aspects of their behavior during their judging of which car to choose, as well as the manner which they seek for information, i.e., the sequence that the decision maker followed during the process: checking if at first they gave priority to opening criterion or alternative cells.

The mapping shows the differences in the manner of seeking for information among the groups. In Group 1, which performed the task with missing information and with time pressure, all experimental subjects opened the information cells of the AHP MAKH-ER by criteria (Figure 4), and in the order in which they were presented, i.e., starting in the first column and so on. It is believed that because of time pressure, individuals led the opening of cells per criterion, and in the order that they were available, so when clicking on the three alternatives of each criterion, the pop up screen was already open, optimizing the time of completing the task. 


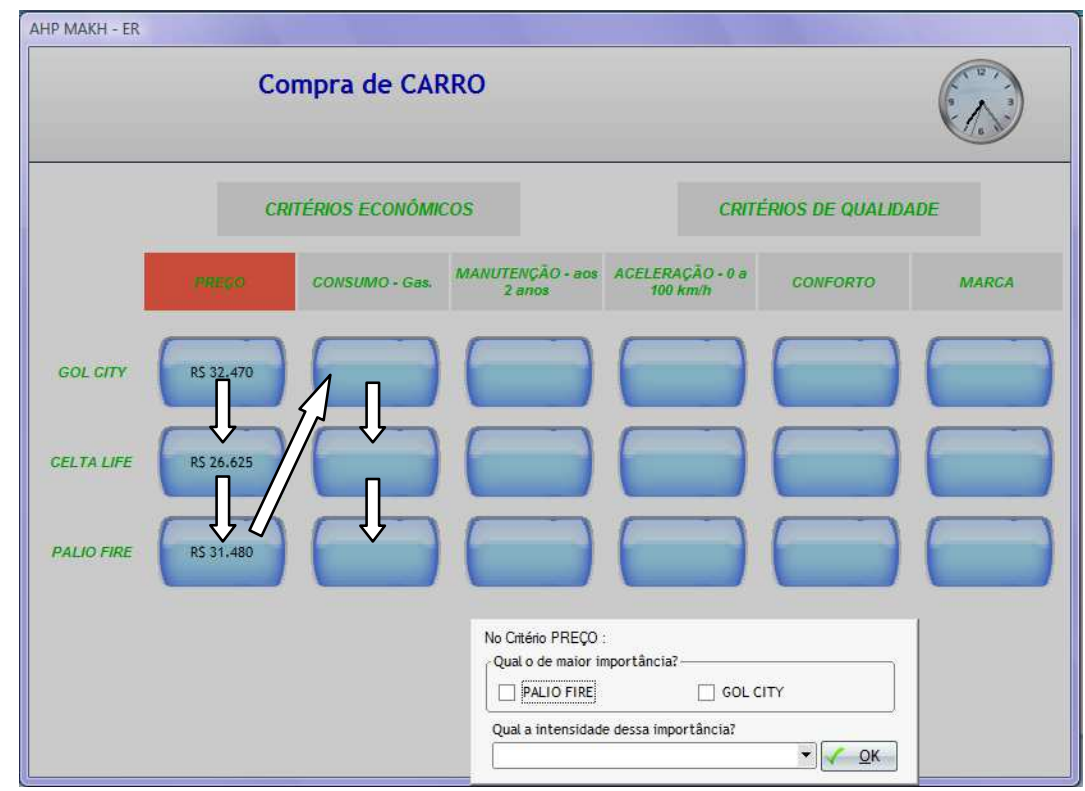

Figure 4 - Search for Information by Criterion

Source: System developed for the research

In Group 2, which also dealt with time pressure, but with no missing information, two (2) of five (5) individuals did not follow this idea of optimization, analyzing the information through the alternatives, according to the sequence shown in Figure 5. However, one of them, after a certain time, perhaps feeling that the time was short, chose to open the cells by criteria, and in order.

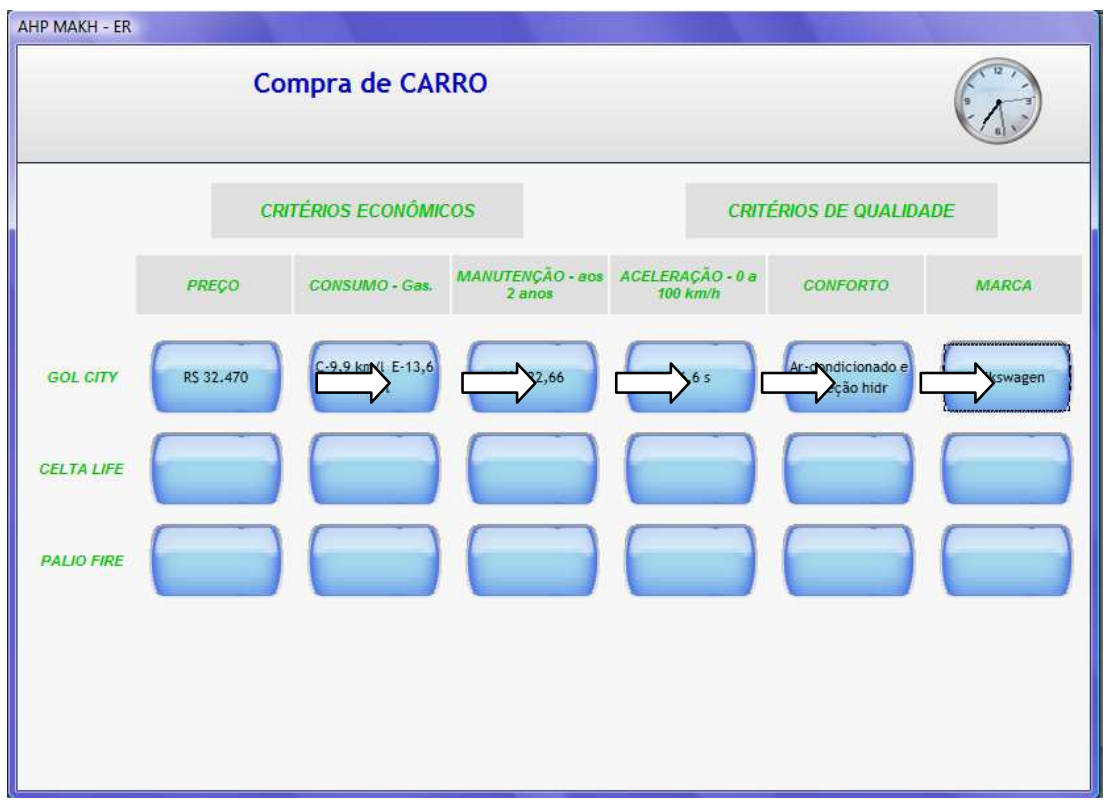

Figure 5 - Search for Information by Alternative

Source: System developed for the research 
In Groups 3 and 4, which did not perform the task under time pressure, it appears that some decision makers opted to seek information by alternative (Figure 5), some in the order presented, others randomly, or even looking for criterion (Figure 4) but not in order. It is inferred that by not having time pressure as a factor, these individuals sought information as their preferences to choose, i.e., whether by criterion or alternative.

\subsection{Analysis of Post-Experiment Questionnaires}

The questionnaire administered to the experimental subjects at the end of the experiment sought to examine the agreement or disagreement with the final car choice , and especially with issues related to missing information and time pressure. These openended questions sought to determine whether in the face of such influences, decisionmakers used any technique or strategy to make things easier, and if they had not had such experience, their decision would have been better. Thus, the questionnaires consisted of the same two (2) questions for all groups, and the others were different for the four groups (GROUP 1, GROUP 2, GROUP 3 and GROUP 4), totaling three (3) questions for G4, which was the control group, five (5) for G2 and G3, and seven (7) for G1, which was influenced by the two variables of the study.

The answers were tabulated and grouped according to similarities. Then, some categories were created to represent a certain group of answers. Soon after, the questions are presented with the answers, in accordance with the experimental group, to highlight the differences found.

When asked if they agreed with the car chosen, shown in the graph of AHP MAKH-ER and if they believed to have made a good choice, the five categories of answers are shown in Table 1. Overall, of the 20 respondents, the vast majority (17) agreed with the final choice shown in the AHP MAKH-ER graph. It is noteworthy that of these, eleven (11) agreed to be the car of their preference, and six (6) for believing that based on the available information it was the best choice. Only two (2) individuals did not agree, because one did not agree with the weights of criteria (1) and another because that model of car was not a priority in their judgments. 


\begin{tabular}{l|c|c|c|c|c}
\hline \multicolumn{1}{c|}{ Categories } & $\begin{array}{c}\text { GROUP 1 } \\
\text { With MI and } \\
\text { With TP }\end{array}$ & $\begin{array}{c}\text { GROUP 2 } \\
\text { With no MI } \\
\text { and With TP }\end{array}$ & $\begin{array}{c}\text { GROUP 3 } \\
\text { With MI } \\
\text { and With } \\
\text { no TP }\end{array}$ & $\begin{array}{c}\text { GROUP 4 } \\
\text { With no } \\
\text { MI and } \\
\text { With no } \\
\text { TP }\end{array}$ & Total \\
\hline $\begin{array}{l}\text { Yes, because the car chosen } \\
\text { represents my preferences }\end{array}$ & 3 & 4 & 2 & 2 & $\mathbf{1 1}$ \\
\hline $\begin{array}{l}\text { Yes, because I believe to } \\
\text { have chosen the best } \\
\text { vehicle, in accordance to the } \\
\text { information given }\end{array}$ & 1 & 1 & 2 & 2 & $\mathbf{6}$ \\
\hline $\begin{array}{l}\text { Yes, because with } \\
\text { information available and } \\
\text { my background knowledge, } \\
\text { it is the best car }\end{array}$ & 1 & 0 & 0 & 0 & $\mathbf{1}$ \\
\hline $\begin{array}{l}\text { No, because I do not agree } \\
\text { with the weight of criteria }\end{array}$ & 0 & 0 & 1 & 0 & 1 \\
\hline $\begin{array}{l}\text { No, because in my answers } \\
\text { the chosen car. }\end{array}$ & 0 & 0 & & & $\mathbf{1}$ \\
\hline
\end{tabular}

Table 1 - Answers related to compliance with the vehicle chosen by experimental group

Making an analysis by experimental group, it appears that Groups 1 and 2, submitted to time pressure, agreed on the final choice, in great majority, because it was their preference of car; while Groups 3 and 4, with no time pressure on the task, also agreed with the choice, but had different opinions regarding the preference of car and the information presented. Those that have not had time pressure on the task were able to better analyze the information available if compared to Groups 1 and 2.

All groups were asked whether they had any difficulty using the system for the process of choosing the car. The three answer categories were: no difficulty (13), time was short (5), and some information was missing (2). It is noteworthy that the majority (13) of 20 experimental subjects said they did not to have difficulty using the system during the task, and five (5) of these were respondents in the control group (Group 4). It should be noted that in Group 1, where time pressure and missing information were dealt with, decision makers reported that only time pressure had been the difficulty factor. This may be due to the fact that, between the two variables that were applied to the task of this group, individuals were more significantly affected by time pressure than by missing information.

Questions 4 to 7 were in the questionnaire according to the Group's exposure to a particular variable of study. Therefore, only the questions of those respondent groups are presented here. For Groups 1 and 2, submitted to the time pressure variable during the experimental task, the following question was asked: Knowing that you had to 
choose under time pressure, did you use any specific technique / strategy to facilitate the task? We obtained four categories, as described in Table 2:

\begin{tabular}{l|c|c|c}
\multicolumn{1}{c|}{ Categories } & $\begin{array}{c}\text { GROUP 1 } \\
\text { With MI and With } \\
\text { TP }\end{array}$ & $\begin{array}{c}\text { With no MI } \\
\text { and With TP }\end{array}$ & Total \\
\hline No technique / strategy & 1 & 1 & $\mathbf{2}$ \\
\hline Yes, I conducted the task in the quickest manner & 2 & 0 & $\mathbf{2}$ \\
\hline Yes, my knowledge about cars & 2 & 0 & $\mathbf{2}$ \\
\hline Yes, I directed my choice to criteria / car of preference & 0 & 4 & $\mathbf{4}$ \\
\hline
\end{tabular}

Table 2 - Answers on the techniques and strategies used to deal with time pressure by experimental group

It is observed that the largest number of answers (4) regarding techniques and strategies to deal with time pressure is directed to the opening of cells of criteria and / or favorite cars. That is, to deal with the short period of time, the subjects make use of their preferences, which have been previously established. It is noteworthy that this strategy was only used by Group 2, which did not have, in addition to time pressure, missing information. As for those who took part in the group with the incidence of both (Group 1 ), the techniques to deal with time were to perform the task more quickly (2), and to make use of knowledge about cars (2).

It was also asked to Groups 1 and 2 if they had had more time to choose, would they have chosen better, and why? And there were four categories of answers among the 10 subjects. The results show that most of them (6) believe that with more time to perform the task, their choices would have been better, because they would have been able to analyze more closely the criteria and / or have different answers. For the remaining respondents (4), more time would not have helped in choosing better, because some were inclined to a particular model of car (2), or worked with cars, making it easy to choose (1), or even, because they had given priority to the analysis of criteria that pleased them (1).

For Groups 1 and 3, with missing information, it was asked: Knowing you had to choose with missing information, did you use any specific technique / strategy to facilitate the task? Table 4 shows that most (6) of the experimental subjects in the groups that performed the task with missing information (10), when facing the task, made use of background knowledge about the object (cars), or made their choices based on their experience in the automobile industry. 


\begin{tabular}{l|c|c|c}
\hline \multicolumn{1}{c|}{ Categories } & $\begin{array}{c}\text { GROUP 1 } \\
\text { With MI and } \\
\text { With TP }\end{array}$ & $\begin{array}{c}\text { GROUP 3 } \\
\text { With MI and } \\
\text { With no TP }\end{array}$ & Total \\
\hline $\begin{array}{l}\text { Yes, between choosing a vehicle about which I have } \\
\text { information and another that I don't, I have always chosen } \\
\text { the first }\end{array}$ & 1 & 1 & $\mathbf{2}$ \\
\hline $\begin{array}{l}\text { Yes, what I know about cars and / or the experience I } \\
\text { have about the subject }\end{array}$ & 4 & 2 & $\mathbf{6}$ \\
\hline $\begin{array}{l}\text { Yes, the knowledge I have about cars, because I did not } \\
\text { use data offered at all }\end{array}$ & 0 & 1 & $\mathbf{1}$ \\
\hline $\begin{array}{l}\text { Yes, I chose the car that seemed good to me considering } \\
\text { other characteristics }\end{array}$ & 0 & 1 & $\mathbf{1}$ \\
\hline
\end{tabular}

Table 4 - Answers on the techniques and strategies used to deal with missing information by experimental group

Another strategy used by two (2) respondents was to choose the vehicle that had information available on that criterion, always discarding the one that did not contain information.

As for the difference between the two groups that dealt with missing information, it appears that in Group 1, also submitted to time pressure, the strategy of four (4) out of five (5) decision makers was to use their knowledge or experience on cars . As for Group 3, which did not suffer time pressure when performing the task, the techniques used to deal with missing information included using previous knowledge / experience (2) choosing the vehicle that had information available (1), choosing by what they knew, not using any of the data available (1), and choosing the car that appealed to their preferences on other criteria (1). It was noted in Groups 1 and 3, however, that when the subjects also suffered time pressure (Group 1) to deal with missing information, they focused on their knowledge and experience to complete the task. As for the group that did not have a preset time (Group 3), they were able to better select their strategies to deal with the issue.

To Groups 1 and 3, with missing information, it was also asked if the missing information could help improve their choice and why? It appears that the majority of respondents (7) believe that missing information could have helped improve their choice if available. However, two (2) of them said they could have improved the process of choice, but would not have changed their chosen model. Three (3) decision makers responded that missing information would not have made their decision any better, because of the knowledge they have on the automobile industry. They were those that dealt with missing information, but with no time pressure (Group 3), which may 
explain that only with missing information this is supplied by the individual's background knowledge.

Now that results obtained by the experimental group have been presented, in order to better understand the behavior of the decision maker, we may proceed to the next section, where we will discuss the main findings and reference them with the literature on this matter.

\section{DISCUSSION: CONCLUSIONS REGARDING THE FINDINGS OF THE EXPERIMENT}

\subsection{Time Pressure Behavior}

It was found that experimental subjects who experienced time pressure, in most cases, sought the information by criteria and not by alternative, as observed in most of the group with no time pressure. Those who started accessing the information by alternative, after a certain time, changed to opening the cells using criteria, in order to prolong the restricted period of time. Edland \& Svenson (1993) state that when time becomes exclusively short, the third step of dealing with the situation (after acceleration and selection) is to change strategies, as Ordóñez \& Benson (1997) have observed. Accordingly, Payne, Bettman \& Luce (1996) report that, when under severe time pressure, people accelerate the processing of information, become more selective, and change strategies to a deeper pattern of processing, based on alternatives, to a broader pattern, based on attributes (criteria).

It is possible to note that when under time pressure, individuals make their choices based on their previous preferences, i.e., on those previous choices that they already have in mind. There are several moments an which this occurs. Initially, it may be observed that the correlation of these subjects with the chosen car is given because it represents their priorities. Subsequently, most decision makers say they use the strategy of directing their choices to criteria / car of preference, when experiencing time pressure. These findings can be justified by the Theory of Image, which asserts that decision makers already have in mind representations and schemes, called images (Seidl \& Traub, 1998), and from there, they lead their decision making process to attain a certain goal that has been pre set.

When Löbler (2006b) verified through an experiment how individuals deal with information in a decision process, he proved that transgressions committed by the experimental subjects are driven by prior expectations and goals. His findings show that decision makers use the strategic image that comes from the Theory of Images to achieve a certain goal. The strategic image, according to Seidl \& Traub (1998), refers to the tactics and plans of the decision maker, that is, the means they use to try to achieve the goals of the trajectory image.

For this same reason, the Theory of Images can also be seen, and perhaps quite clearly, when some decision makers, if not most of them, say that if they had more time to accomplish the task, this would not help them make a better choice, because they were already inclined to a certain model of car. Thus, the Theory of Images can explain the findings of this study, regarding the use of previous preferences to face time 
pressure.

Other techniques for dealing with time pressure were also observed. Some individuals stated that, when faced with such situation, they used their knowledge about the object. Such respondents were those belonging to Group 1, which, in addition to time pressure, also suffered missing information; specifically, those in Groups 1 and 3 revealed that the use of knowledge was the main strategy, as discussed later. By performing an experiment to evaluate the information processing of individuals with different levels of knowledge, Löbler (2005) found that those with more knowledge, since they have more knowledge about the object in question, tend to disregard the objective information provided by the system and use their prior knowledge about the subject. The findings of the author may be well justified in the use of prior knowledge as a strategy for dealing with time pressure, since the respondents were individuals who had good understanding of the subject matter.

The explanation can come from the findings of Tversky \& Kahneman (1974), according to both authors, individuals seek shortcuts called heuristics. The rational model cannot explain how the decision-making process actually happens, since it is based on a set of assumptions that determine how a decision should be made, rather than how decision is actually made.

Another strategy of the decision makers was to accomplish the task more quickly, which speeds up the processing of information (Payne, Bettman \& Luce, 1996). Because time is perceived as being shorter (Fisher, Chengalur-Smith \& Ballou, 2003), one must limit the time for the task (Smith \& Hayne, 1997). In this regard, De Dreu (2003) ensures that under time pressure, individuals are less motivated to process information systematically, being more influenced by cognitive heuristics, and thus spending less time making decisions. This is corroborated by Rieskamp \& Hoffrage (2007) when they state that under high time pressure individuals accelerate the search for information, using less information, and staying focused on the most important features.

It was observed that respondents who suffered time pressure, as well as missing information, were more affected by time pressure than missing information, when asked about the difficulties encountered when using the AHP MAKH-ER in the selection process. This finding may be due to the negative behavior that time pressure causes on individuals, like the closing of the mind (Kruglanski \& Freund, 1983), the feeling of stress (Benson \& Ordóñez, 1997), which consequently leads the individual to fault and bad judgments (Ahituv, Igbaria \& Sella, 1998), preventing the complete and profound processing of information (Kocher \& Sutter, 2006). Thus, such feelings can be more noticeable by the individuals than missing information, when in a decision making situation.

\subsection{Missing information Behavior}

The answers of subjects, who experienced missing information to perform the task, show that their background knowledge, as well as the experience that the individual has regarding the object of choice, is the most frequently used coping technique. The strategy of using prior knowledge and experience is briefly discussed by Hsu \& Mo (2009). The authors sought to examine how consumers perceived missing 
information in print ads and in fashion magazines, trying to identify how missing information affected their decisions. In general, consumers who had high levels of involvement with the advertising tended to give more attention to missing information and were more likely to seek information. On the other hand, consumers who had lower levels of involvement tended to ignore the missing information. Regarding this, Hsu \& Mo (2009) argue that missing information could be inferred through previous experiences with decision making. Such strategy was demonstrated in this study to address missing information.

Another coping strategy verified twice in the post-experiment questionnaire was that, given the missing information, decision makers prefer to choose the alternative in which information is available for that criterion, totally discarding the one in which the information is missing. This finding concurs with Körner et al. (2007) who confirmed that the individuals give more weight to those aspects in common (with available data) than the unique dimensions (with missing information).

Even though verified by only one experimental subject, it is important to underline that, to deal with the missing information, the subject used knowledge of the object, totally rejecting the data available in the AHP MAKH-ER during the task, showing extreme self confidence. The same individual showed similar behavior reporting difficulties with the system, which was considered confusing and not designed by a person knowledgeable about cars. This self confidence is a concern highlighted by Löbler (2006b) that decision makers have values so heavily rooted in their knowledge structure, that they guide all subsequent processes, causing them to remove information that does not suit their beliefs or to overvalue information that does. In this study, when dealing with missing information, the subject was confident to disregard information, even those that were available in the system, believing in their prior information.

The explanation for the behavior described above can be found in Tversky and Kahneman (1974) and Bazerman (2004) when they explain that some individuals' decisions are based on the available heuristic, which leads to ease of recall bias, i.e., individuals base their decisions on those most vivid memories, while disregarding those that are less available, but that may be important for the decision.

Self-confidence was also observed in the question that asked whether the missing information would help improve the choice. Some decision makers said that it could even improve the choice, but it would not change the chosen car. Note here that if the information was not missing, such information could qualify the decision-making process, but would not reach the final choice of the individual, who is confident in their judgments. The same applies to those who responded that the missing information would not improve their choice because they are experts in the field of the object in question, which shows overconfidence in their own knowledge. Again, in Löbler (2005) may lie the justification for the decision maker's self confidence, in which individuals with more knowledge, grounded in their knowledge about the object of the decision, use more of their own knowledge on the subject, causing them to disregard even more the information provided by the DSS. 


\begin{tabular}{|c|c|c|}
\hline $\begin{array}{l}\text { Independent } \\
\text { Variable }\end{array}$ & DECISION MAKER BEHA VIOR & THEORETICAL BASIS \\
\hline \multirow{5}{*}{ TIME PRESSURE } & $\begin{array}{l}\text { Searches information by criterion } \\
\text { Changes strategy (alternative to } \\
\text { criterion) }\end{array}$ & $\begin{array}{c}\text { Edland \& Svenson (1993); } \\
\text { Ordóñez \& Benson (1997); } \\
\text { Payne, Bettman \& Luce (1996) }\end{array}$ \\
\hline & Chooses based on previous preferences & $\begin{array}{c}\text { Seidl \& Traub (1998) and } \\
\text { Löbler (2006b) - Theory of } \\
\text { Image }\end{array}$ \\
\hline & $\begin{array}{l}\text { Uses background knowledge about the } \\
\text { object }\end{array}$ & Löbler (2005) \\
\hline & $\begin{array}{l}\text { Accelerates the processing of } \\
\text { information }\end{array}$ & $\begin{array}{c}\text { Payne, Bettman \& Luce (1996); } \\
\text { De Dreu (2003); Rieskamp \& } \\
\text { Hoffrage (2007) }\end{array}$ \\
\hline & $\begin{array}{l}\text { Feels Time Pressure more than Missing } \\
\text { information }\end{array}$ & $\begin{array}{l}\text { Kruglanski \& Freund (1983) - } \\
\text { Closing of the Mind; Ordóñez } \\
\text { \& Benson (1997) - Feeling of } \\
\text { stress }\end{array}$ \\
\hline \multirow{3}{*}{$\begin{array}{l}\text { MISSING } \\
\text { INFORMATION }\end{array}$} & $\begin{array}{l}\text { Uses background knowledge and } \\
\text { experience }\end{array}$ & Hsu \& Mo (2009) \\
\hline & $\begin{array}{l}\text { Chooses the alternative in which } \\
\text { information is available }\end{array}$ & Körner et al. (2007) \\
\hline & Shows self-confidence & $\begin{array}{l}\text { Löbler (2005); } \\
\text { Löbler (2006b) }\end{array}$ \\
\hline
\end{tabular}

Table 4 - Summary of results of the experiment with theoretical underpinning and references

Table 4 is presented in order to demonstrate a short view of this study, with two independent variables of the experiment and the main findings about the behavior of the decision maker, verified in the mapping process and in the questionnaire with open questions, which was applied after the experiment; as well as the theoretical foundations that underpin these findings.

\section{FINAL REMARKS}

Although it may be considered an exploratory work in its essence, since it is the first time these variables have been tested in Brazil, it is important to note here some conclusions that could guide research following the same line shortly. The results of this study provide evidence to state that decision makers have specific strategies for dealing with time pressure and missing information. Under time pressure the individuals sought information on criteria, or they changed their strategy: starting by alternative and then by criterion. When under time pressure, the experimental subjects focused on the car of their choice; whereas with no time pressure, some of them rationalized more, used the information, and did not agree with the chosen car.

Assumptions of the Theory of Images also justified some findings, indicating that previously structured images in the mind of the decision maker, which represent 
their preferences, are a way of coping with time pressure. Still regarding this variable, it was found that decision makers speed up the processing of information, performing the task faster, and thus feeling the time pressure more intensely, in the form of blocking the mind and having a feeling of stress, than the missing information when subjected to both variables.

Given the missing information, the use of background knowledge and individual experience was the most prominent coping strategy. Less frequently, but it deserves to be emphasized, self-confidence was also noted in some subjects when experiencing missing information during the task and the choice of the alternative in which information was available (when compared to other alternative with no information). In this regard, given the time pressure and missing information that decision makers face daily, the strategies that emerged in this study may come perhaps to facilitate the understanding of some kind of future action of the decision maker.

Among all the limitations related to a scientific work, the main limitation of this study is the fact that experimental research in the field of social sciences was conducted, where total control of the dependent and independent variables is something virtually impossible to happen (Triviños, 1995). However, we sought to address this issue properly, within the limits of social science research. Another limitation is the low number of experimental subjects, which entails possibilities of replication of the study with a larger number of subjects.

Another point to note as a suggestion for future research is the possibility of evaluating more carefully some issues that emerged in this study and seem to be related to influences of heuristics and biases adressed by Tversky and Kahnmann (1974) and Bazerman (2004), for example, disregard for the information system and use of prior knowledge on the subject. Another approach may be to include the theory of prospects in this type of experiment, because it may bring some explanations related to the behavior of decision makers from the presentation of information. Also, it could include feelings of loss and gain in the decision under time pressure and missing information to see how decision makers would react as of the change of these two variables based on theory proposed by Kahnemann and Tversky (1979).

Regarding collection techniques to be used to study the time pressure and missing information in decision making, it is suggested a further study with qualitative methods such as interviews and observation, which allow individuals to evoke revealing features. It also proposes the study through the use of a protocol analysis, a technique known as "the think-aloud method", which suggests collecting information about people's thoughts during a variety of cognitive tasks. The verbalization process reveals the assumptions, conclusions, misconceptions and problems that users face when solving problems or performing tasks (Ericsson \& Simon, 1993), which in the context of this study would provide a better understanding of the behavior of the decisionmaker, allowing, perhaps, to find the best strategies to cope with time pressure and missing information. 


\section{REFERENCES}

Ahituv, N., Igbaria, M., \& Sella, A. (1998). The Effects of Time Pressure and Completeness of Information on Decision Making. Journal of Management Information Systems, 15(2), 153-172.

Berto, A. R. Jogos de Empresas: Avaliação da cognição em relação ao processo de tomada de decisão e formação de estratégia. Congresso Virtual de Brasileiro de Administração. Recuperado em 29 jul, 2007, de $<$ http://www.convibra.com.br/pdf/66.pdf $>$.

Birgelen, M., Ruyter, K., \& Wetzels, M. (2000). The Impact of Incomplete Information on the Use of Marketing Research Intelligence in International Service Settings. Journal of Service Research, 2(4), 372-387.

Corso, K. B.; Löbler, M. L. (2010). AHP MAKH-ER: Validação de um sistema de apoio à decisão para estudar a influência da pressão do tempo e da falta de informação no processo decisório. Produto e Produção, v. 11, n.2, p.45-58.

Cozby, P. C. (2006). Métodos de pesquisa em ciências do comportamento. São Paulo: Atlas.

De Dreu, C. K. W. (2003). Time pressure and closing of the mind in negotiation. Organizational Behavior and Human Decision Processes. v. 91, 280-295.

Ebenbach, D. H., \& Moore, C. F. (2000). Incomplete Information, Inferences, and Individual Differences: The Case of Environmental Judgments. Organizational Behavior and Human Decision Processes, 81(1), 1-27.

Edland, A., \& Svenson, O. (1993). Judgment and Decision Making under Time Pressure: Studies and Findings. In: Svenson, O.; Maule, J. (Eds.). Time pressure and stress in human judgment and decision making. New York: Plenum,

Ericsson, K. A., \& Simon, H. A. (1993). Protocol analysis: verbal reports as data. MIT Press.

Fachin, O. (2002). Fundamentos de Metodologia. 3. ed. São Paulo: Saraiva.

Fisher, C. W., Chengalur-Smith, I. S., \& Ballou, D. P. (2003). The impact of experience and time on the use of data quality information in decision making. Information Systems Research, 14(2).

Hsu, J. L., \& Mo, R. H. C. (2009). Consumer responses to incomplete information in print apparel advertising. Journal of Fashion Marketing and Management, 13(1), 66-78.

Jagacinski, C. M. (1991). Personnel Decision Making: The Impact of Missing Information. Journal of Applied Psychology, 76(1), 19-30.

Kivetz, R., \& Simonson, I. (2000). The Effects of Incomplete Information on Consumer Choice. Journal of Marketing Research. v. 37, p. 427-448.

Kocher, M. G., \& Sutter, M. (2006). Time is money: time pressure, incentives, and the 
quality of decision-making. Journal of Economic Behavior and Organization, v. 61, 375-392.

Körner, C., Gertzen, H., Bettinger, C., \& Albert, D. (2007). Comparative judgments with missing information: A regression and process tracing analysis. Acta Psychologica. v. $125,66-84$.

Kruglanski, A.W., \& Freund, T. (1983). The freezing and unfreezing of lay-inferences: effects of impressional primacy, ethnic stereotyping, and numerical anchoring. Journal of Experimental Social Psychology, v. 19, 448-468.

Löbler, M. L. (2005). Processamento da Informação: Uma avaliação dos diferentes níveis de conhecimento no processo de decisão. 2005. 214f. Tese (Doutorado em Administração) - Escola de Administração, Programa de Pós-Graduação em Administração, Universidade Federal do Rio Grande do Sul, Porto Alegre.

Löbler, M. L. (2006b). A Teoria da Imagem como Explicação para Violação do Método Multicritério de Decisão. Salvador/BA. Anais do $30^{\circ}$ ENANPAD, ANPAD.

Löbler, M. L., \& Hoppen, N. (2005). Uso da Informação e Estratégias de Decisão na Interação com um SAD. Brasília/DF. Anais do $29^{\circ}$ ENANPAD, ANPAD.

Maule, A. J., \& Hockey, G. R. (1993). State, Stress, and Time Pressure. In: SVENSON, O.; MAULE, J. (Eds.). Time pressure and stress in human judgment and decision making. New York: Plenum.

Maule, A. J., \& Svenson, O. (1993). Theoretical and empirical approaches to behavioral decision Making and their relation to time constraints. In: SVENSON, O.; MAULE, J. (Eds.). Time pressure and stress in human judgment and decision making. New York: Plenum.

Ordóñez, L., \& Benson III, L. (1997). Decisions under Time Pressure: How Time Constraint Affects Risky Decison Making. Organizational Behavior and Human Decision Processes, 71(2), 121-140.

Payne, J. W., Bettman, J. R., \& Johnson, E. J. (1993). The adaptive decision maker. Cambridge University Press.

Payne, J. W., Bettman, J. R., \& Luce, M. F. (1996). When Time Is Money: Decision Behavior under Opportunity-Cost Time Pressure. Organizational Behavior and Human Decision Processes, 66(2), 131-152.

Pereira, M. J. L., \& Fonseca, J. G. M. (1997). Faces da decisão: as mudanças de paradigmas e o poder da decisão. São Paulo: Makron Books. 